\title{
The Relationship of Knowledge and Parents' Attitudes with Children's Potty Training in Gampong Ujong Drien
}

\author{
${ }^{1}$ Fitrah Reynaldi, ${ }^{1}$ Safrizal Safrizal, ${ }^{1}$ Yarmaliza Yarmaliza, ${ }^{1}$ Teungku Nih Farisni, ${ }^{1}$ Fitriani Fitriani, \\ ${ }^{1}$ Zakiyuddin Zakiyuddin, ${ }^{1}$ Darmawi Darmawi \\ ${ }^{1}$ Fakultas Kesehatan Masyarakat Universitas Teuku Umar \\ Corresponding author's email: fitrahreynaldi@utu.ac.id
}

Submitted: 09/02/2019 Revised: 14/03/2019 Accepted: 02/04/2019

How to cite this article:

Reynaldi, F., Safrizal, S., Yarmaliza, Y., Farisni, T., Fitriani, F., Zakiyuddin, Z., \& Darmawi, D. (2019). The relationship of knowledge and parents' attitudes with children's potty training in Gampong Ujong Drien. J-KESMAS, 6(1), 10-13

\begin{abstract}
One of the ideals of a nation is to produce a healthy and smart generation. Good generations in the future are formed from the first 1000 days of life to the age of 5 years. An important stimulus is to foster a child's independence in urinating and defecating in the toilet. The strategy that can be done by parents in teaching their children $\mathrm{BAB}$ and BAK is through potty training. The purpose of this study was to determine the relationship of knowledge and attitudes with potty training in under three years child's. This research is analytic with cross sectional design. A sample of 40 toddler parents were taken using the total population technique. Chi Square test the relationship of parental knowledge with potty training obtained P Value $0.002<0.05$ so that parental knowledge with the implementation of potty training has a significant relationship. Chi Square test the relationship between parental attitudes with potty training obtained P Value $0.004<0.05$ so that parental attitudes with the implementation of potty training have a significant relationship. The conclusion of this study is that knowledge and attitudes have a significant relationship with potty training in under three years child's. It is recommended to the Puskesmas to make an introduction to potty training programs for parents so that the implementation of potty training can be achieved optimally.
\end{abstract}

\section{Keywords}

Knowledge; attitude; potty training; under three years child

\section{Introduction}

The formation of a healthy and smart generation is mandatory from the beginning of one's life. It is important for parents to create basic growth and development of children in children under three years. Growth and development that will produce a healthy generation of quality in the future. An important stimulus is to develop the child's independence in urinating and defecating in the toilet 
Strategies that can be applied by parents to be invited and familiarized with defecating and urinating in the toilet are with potty training. Potty training is important to practice to train the child's independence and as a stimulation for other developments. Potty training is useful in instilling good in children, especially in terms of personal hygiene. Potty training must be practiced when children start the age of three. If the potty training is carried out at the wrong time, then the child will have difficulty in his development and abilities. It is not easy to mean potty training for children, but it does not mean this makes parents ignorant about the problem.

Knowledge and attitude of parents about toilet training is very important. Because it will be related to the application of potty training in children. Parents who have good knowledge and attitude automatically have a good understanding of the benefits and understanding of potty training. The purpose of this study was to study the relationship of knowledge and attitudes of parents with potty training in under three years child's in Ujong Drien Village, Meureubo District, West Aceh Regency.

\section{Method}

This research is analytic with cross sectional design (measuring the dependent and independent variables at the same time with one visit for the results of the study), which is to determine the relationship of knowledge and attitudes of parents with potty training in under three years child's. The sample in this study were 40 under three years child's parents taken using the total population technique. Data collection uses primary data and secondary data. Testing data using the chi square test to prove the hypothesis with the provisions if $\mathrm{p}$ value $<0.05$ (Ho is rejected) so that it is concluded that $\mathrm{Ha}$ is correct which means there is a meaningful relationship.

\section{Results}

Based on table 1, it can be seen that the age of the most dominant respondents is $>30$ years category that is $90 \%$. Based on table 2, it can be seen that the most dominant respondent education is the high school graduation category at $65 \%$. Based on table 3 , it can be seen that the parents' knowledge of potty training in under three years child's is the most dominant category that is not good that is $90 \%$. Based on table 4 , it can be seen that the attitude of parents

of potty training in under three years child's, the most dominant is the unfavorable category that is $62.5 \%$. Based on table 5 , it can be seen that the implementation of potty training on the most dominant under three years child's is the unsuccessful category that is $85 \%$. Table 6 shows that of the 4 respondents who were well knowledgeed there were $75 \%$ of respondents who had successfully implemented potty training. While of the 36 respondents who lack knowledge, there were $83.3 \%$ of respondents whose potty training was not successful. From the Chi Square test results obtained P Value $0.002<0.05$ so that it can be concluded that there is a relationship between the knowledge of parents with the implementation of potty training in under three years in Ujong Drien Meureubo District, West Aceh Regency.

Table 7 shows that out of the 15 respondents who had a good attitude, 33.4\% of respondents had successful potty training. While of the 25 respondents who behaved unfavorably there were $96 \%$ of respondents whose potty training implementation category was unsuccessful. From the Chi Square test results obtained P Value $0.004<0.05$ so that it can be concluded that there is a 
relationship between the attitudes of parents with the implementation of potty training in Under three years child's in Kampung Ujong Drien, Meureubo District, West Aceh Regency.

\section{Discussion}

There is $90 \%$ of parents' knowledge of potty training in under three years child's in Ujong Drien Village, Meureubo Subdistrict, which is classified as poor. This indicates that parents still do not understand and pay attention to the importance of potty training in under three years child's. In daily life, allowing ordinary children to defecate and urinate carelessly will result in the child's character will become less good as the child will be lazy, irresponsible, and the most dangerous thing is that the child cannot independently control the bowel movements urinate and defecate.

Chi Square test results obtained P Value $0.002<0.05$ so it can be concluded that there is a relationship between parents' knowledge and the implementation of potty training in toddlers in Ujong Drien Village, Meureubo District. Kiddoo's and Wahida's research is in line with this research which suggests that there is a relationship between knowledge and the implementation of potty training in under three years child's.

Knowledge is a very important area in shaping one's character. It is known that behaviors that are based on knowledge will last longer than those that are not based on knowledge. In this study, it can also be seen that the attitude of parents towards potty training in toddlers is the most dominant category that is not good that is $62.5 \%$. Usually attitudes and knowledge don't have much difference because attitudes will follow someone's knowledge ${ }^{8}$. Busyness of parents is a major factor in the failure of potty training in toddlers. Parents prefer to put diapers on their children rather than let the child go to the toilet.

Chi Square test results obtained P Value $0.004<0.05$ so it can be concluded that there is a relationship between the attitudes of parents with the implementation of potty training in toddlers in Ujong Drien Village, Meureubo District, West Aceh Regency. Kiddoo's and Wahida's research is in line with this research which suggests that there is a relationship between attitude and the implementation of potty training in under three years child's.

\section{Conclusions}

There is a relationship between parents' knowledge and attitudes with the implementation of potty training for toddlers in Ujong Drien Village, Meureubo District, West Aceh Regency. To the Puskesmas to make an introduction to potty training programs for parents so that the implementation of potty training can be achieved optimally.

\section{Author Contribution and Competing Interest}

The first author was a lead investigator and is the corresponding author. The others helped the first author in analyzing and writing the research. There was no competing interest related to the conduct of this study. 


\section{References}

Ardhiyanti, L. P. (2015). Hubungan Antara Pendidikan Ibu Dengan Keberhasilan Potty Training Pada Batita Umur 1-3 Tahun Di Bpm Ny. Hj. Nieemah Madzumi, S. St, MM Kes Desa Bawangan Kecamatan Ploso Kabupaten Jombang. Jurnal Kebidanan, 9(1).

Brazelton, T. B., 1962. A Child-Oriented Approach to Potty Training. Pediatrics

Colson, E. R., Dworkin, P. H., 1997. Toddler Development. Pediatr. DeBord,K., 1997. Potty Training-Preparing Your Child to Use The Potty. University of New Hampshire

Ferrer-Chancy, M., McCrea, S., 2000. Potty Training. University of Florida

Gilbert, Jane. (2006). Latihan Potty: Panduan Melatih Anak untuk Mengatasi Masalah Potty (Wisyananto Suranto, Penerjemah). Jakarta: Erlangga

Irmaatus, S. (2009). Gambaran Pengetahuan Ibu tentang kesiapan potty training pada anak usia 18-24 bulan di dusun Pandantoyo Kecamatan Ngancar Kabupaten Kediri. Universitas Gadjah Mada. Diakses 06 Desember 2016.

Kiddoo, D. A. Potty Training Children: When To Start And How To Train. DOI: 10.1503/cmaj.110830

Wahida, N. (2016). Gambaran Pengetahuan Dan Sikap Ibu Tentang Potty Training Di Pendidikan Anak Usia Dini (Paud) Qurratu „Aini Kecamatan Mandiangin Koto Selayan Kota Bukittinggi. Jurnal Kesehatan, 3(1)

Triningsih, T. (2014). Pengaruh Pendidikan Kesehatan Potty Training Terhadap Tingkat Pengetahuan Ibu Tentang Potty Training Di Paud Tunas Harapan Kutoarjo Purworejo. Jurnal Komunikasi Kesehatan, 5(2). 